WAHATUL MUJTAMA': Jurnal Pengabdian Masyarakat

Vol. 1, No. 1 (2020) : Hal. 54-66

Website: https://journal.stiba.ac.id

\title{
FESTIVAL ANAK SALEH DI DESA LEANG-LEANG KABUPATEN MAROS
}

\author{
Aswar \\ Sekolah Tinggi Ilmu Islam dan Bahasa Arab (STIBA) Makassar \\ aswar@stiba.ac.id \\ Rosmita \\ Sekolah Tinggi Ilmu Islam dan Bahasa Arab (STIBA) Makassar \\ rosmt84@gmail.com
}

\begin{abstract}
Keywords :
ABSTRACT

Virtuous, Courtesy, Morals

Community service (PkM) is one pillar of Tri Dharma in Higher Education. One form of its realization is cooperation between the regional government and universities in the form of implementing KKN that is sustainable and provides mutual benefit (symbiosis of mutualism). The purpose of this PkM was to improve the competence, morals, and attitude of elementary-school-age children in LeangLeang village through the implementation of a program titled "Virtuous Children's Festival" (FAS) organized by the students of Community Service Program (KKN) III STIBA Makassar, which was directly guided by a Field Supervisor (DPL). As for the forms of competition in FAS those were: Adhan competition, Musabaqah Tilawatil Quran (MTQ), Musabaqah Hifdzil Quran (MHQ), Islamic Intelligence Quiz (CCI), and Little Da'i. Method of the implementation of the program was analyzing the needs of elementary-school-age children, planning, implementing, and evaluating and following up on activities. The results of PkM are that elementary-school-age children have had basic Islamic knowledge, memorized short letters of Quran and daily prayers, and are enthusiastic in learning Quran.
\end{abstract}

\section{Kata kunci :}

Saleh, Adab, Akhlak.

\section{ABSTRAK}

Pengabdian kepada masyarakat (PkM) adalah merupakan salah satu pilar dari Tri Dharma Perguruan Tinggi. Salah satu wujud realisasinya yakni melalui kerjasama antara pemerintah daerah dengan perguruan tinggi dalam bentuk pelaksanaan $\mathrm{KKN}$ yang bersifat sustainable (berkelanjutan) dan saling memberi kebermanfaatan (simbiosis mutualisme). Tujuan dari PkM ini adalah untuk meningkatkan kompetensi, akhlak, dan adab anak-anak usia sekolah dasar di kelurahan Leang-Leang melalui pelaksanaan program kegiatan yang bertajuk "Festival Anak Saleh" (FAS) yang diadakan oleh mahasiswa KKN angkatan III STIBA Makassar yang dibimbing langsung oleh Dosen Pembimbing Lapangan (DPL). Adapun bentuk-bentuk perlombaan dalam FAS yaitu: lomba Adzan, Musabaqah Tilawatil Quran (MTQ), Musabaqah Hifdzil Quran (MHQ), Cerdas Cermat Islam (CCI), dan Da'i Cilik. Metode pelaksanaan kegiatan yaitu dengan cara analisis kebutuhan anakanak usia sekolah dasar, perencanaan, pelaksanaan, dan evaluasi serta follow up kegiatan. Hasil dari PkM ini adalah anak-anak usia sekolah dasar telah memiliki pengetahuan Islam dasar, hafalan surat- 
WAHATUL MUJTAMA': Jurnal Pengabdian Masyarakat

Vol. 1, No. 1 (2020) : Hal. 54-66

Website: https://journal.stiba.ac.id

surat pendek, dan doa-doa harian, serta antusias dalam mempelajari Alquran. 
WAHATUL MUJTAMA': Jurnal Pengabdian Masyarakat

Vol. 1, No. 1 (2020) : Hal. 54-66

Website: https://journal.stiba.ac.id

\section{PENDAHULUAN}

Kelurahan Leang-Leang adalah salah satu wilayah dari 8 (delapan) kelurahan/desa yang ada di Kecamatan Bantimurung Kabupaten Maros Provinsi Sulawesi Selatan. Berdasarkan letak geografis Kelurahan Leang-Leang berada diposisi dari sebelah utara berbatasan dengan Kelurahan Balleanging (Kabupaten Pengkep), sebelah selatan berbatasan dengan Kelurahan Kallabirang (Kabupaten Maros), sebelah timur berbatasan dengan Desa Labuaja (Kabupaten Maros), dan sebelah barat berbatasan dengan Desa Mangeloreng (Kabupaten Maros). ${ }^{1}$

Kata Leang-Leang itu sendiri adalah reduplikasi penuh atau pengulangan utuh dari kata dasar "Leang" dalam bahasa Makassar bermakna "Gua" dan makna reduplikasi tersebut menyatakan himpunan beberapa atau lebih dari satu. Jadi, Leang-Leang adalah himpunan yang terdiri dari beberapa gua. Kelurahan Leang-Leang berstatus sebagai kelurahan definitif dan tergolong pula sebagai kelurahan swadaya. Kelurahan LeangLeang memiliki luas wilayah $10,70 \mathrm{~km}^{2}$ dan jumlah penduduk sebanyak 2.347 jiwa dengan tingkat kepadatan penduduk sebanyak 219,35 jiwa/ $\mathrm{km}^{2}$ pada tahun 2017. Kelurahan Leang-Leang, khususnya lingkungan Leang-Leang sebagian kecil termasuk dalam kawasan Taman Nasional Bantimurung-Bulusaraung dimana terdapat pegunungan karst yang sudah berumur ribuan tahun dan terbesar kedua di dunia setelah di Guangzhou, Tiongkok. Meliputi area seluas 43.750 hektar, wilayah ini memiliki 286 gua dengan lebih dari 30 gua prasejarah.

Data profil Kelurahan Leang-Leang juga menunjukkan potensi sumber daya manusia yang dapat dikembangkan dengan baik. Utamanya pengembangan pendidikan pada anak berusia sekolah dasar. Pada rentang usia 6 - 12 tahun yang merupakan usia sekolah dasar, ditemukan jumlah anak laki-laki sebanyak 154 jiwa dan jumlah anak perempuan sebanyak . Berikut data yang diperoleh dari profil Kelurahan Leang-Leang:

\begin{tabular}{ccc}
\hline USIA & LAKI-LAKI & PEREMPUAN \\
\hline 6 & 30 orang & 24 orang \\
\hline 7 & 22 orang & 19 orang \\
\hline 8 & 22 orang & 26 orang \\
\hline 9 & 21 orang & 21 orang \\
\hline 10 & 17 orang & 19 orang \\
\hline 11 & 18 orang & 24 orang \\
\hline 12 & 23 orang & 31 orang \\
\hline Jumlah & 154 Orang & 164 Orang \\
\hline
\end{tabular}

Sumber Data: Profil Kelurahan Leang-Leang Tahun 2019.

${ }^{1}$ Profil Kelurahan Leang-Leang Tahun 2019.

Aswar, Rosmita. Festival Anak Saleh ... 
Data di atas gayut atas penuturan salah seorang Ibu ketua Majelis Pengajian di Leang-Leang yang bertutur bahwa: "disini nak, banyak anak-anak yang mau belajar Alquran, tapi kurang-ki' pengajarnya, orang tuanya juga semua sibuk ke sawah, apalagi sekarang musim tanam; dan butuh-ki' juga diadakan semacam perlombaan mengaji untuk motivasi anak dan orang tuanya" (Informan berinisial WR, tanggal 7 Januari 2020).

Berdasarkan profil data dan curhatan ketua Ibu Majelis Taklim Leang-Leang di atas, patut untuk kemudian diupayakan program kegiatan yang bersifat edukatif dalam rangka pengembangan kompetensi, akhlak, dan adab anak-anak dalam menghadapi masa depannya. Tentunya, pemerintah dapat melakukan kerjasama dengan pihak perguruan tinggi yang sifatnya sustainable (berkelanjutan) dan saling memperoleh kebermanfaatan (simbiosis mutualisme). Upaya tersebut dapat disinergikan dalam bentuk PkM (Pengabdian Kepada Masyarakat) yang merupakan salah satu pilar pengembangan Tri Dharma Perguruan Tinggi.

KKN (Kuliah Kerja Nyata) merupakan salah satu mata kuliah yang wajib untuk dipenuhi oleh mahasiswa/i Sekolah Tinggi Ilmu Islam dan Bahasa Arab (STIBA) Makassar dalam menyelesaikan beban studinya di perguruan tinggi. Pada tahun akademik 2019/2020 STIBA Makassar menyelenggarakan kerjasama KKN angkatan III dengan pemerintah Kecamatan Bantimurung Kabupaten Maros Provinsi Sulawesi Selatan. Kelurahan Leang-Leang adalah salah satu posko penempatan mahasiswa KKN STIBA Makassar angkatan III di wilayah Kecamatan Bantimurung yang menempatkan mahasiswa sebanyak 9 mahasiswa dan 11 mahasiswi.

Pada data sebelumnya, maka program-program yang akan dilaksanakan adalah berbasis kebutuhan atau berdasarkan hasil survei dan potensi serta permasalahan yang ada di lokasi KKN, Kelurahan Leang-Leang. Program tersebut dinilai dapat berkontribusi aktif dalam penyelesaian masalah yang ada di kelurahan, mencakup peningkatan mutu Pendidikan, Kesehatan, Sosial dan Keagamaan. Berdasarkan pengamatan dan analisis kebutuhan program diperuntukkan untuk anak-anak usia sekolah dasar, maka program pengajaran Alquran dan festival anak saleh dianggap cocok untuk meretas masalah dan mengembangkan kompetensi, akhlak dan adab anak-anak di kelurahan Leang-Leang.

Hasil PkM sebelumnya, yang dilaksanakan oleh Ika Maryani dan Nanda Noveryal juga menunjukkan bahwa kegiatan Festival Anak Saleh mampu menjadikan anak termotivasi dalam mempelajari agama Islam sekaligus sebagai sarana mengembangkan bakat dan minat anak. ${ }^{2}$ Demikian juga hasil PkM yang dilakukan oleh Pangestu, dkk., menunjukkan bahwa anak-anak di Dusun Pakel juga memiliki rasa percaya diri yang

\footnotetext{
${ }^{2}$ Maryani, I., \& Noveryal, N. Penyelenggaraan Festival Anak Saleh di Dusun Seropan I, Desa Munthuk, Kecamatan Dlingo. Jurnal Pemberdayaan: Publikasi Hasil Pengabdian Kepada Masyarakat, vol.3, No.2, (2019): 131-136.
} 
WAHATUL MUJTAMA': Jurnal Pengabdian Masyarakat

Vol. 1, No. 1 (2020) : Hal. 54-66

Website: https://journal.stiba.ac.id

meningkat setelah mengikuti program festival anak saleh. ${ }^{3}$ Dengan demikian, hasil pagelaran festival anak saleh yang dilaksanakan oleh mahasiswa STIBA Makassar angkatan III di Kelurahan Leang-Leang juga diekspektasikan agar semakin memperkaya eksistensi pemberdayaan masyarakat di Indonesia.

Pelaksanaan KKN STIBA Makassar Angkatan III tahun 2020, pelaksanaannya dimulai pada tanggal 6 Januari 2020 sampai dengan tanggal 24 Februari 2020, yang pelaksanaannya dilakukan oleh mahasiswa KKN dan masyarakat Kelurahan LeangLeang Kecamatan Bantimurung, Kabupaten Maros. Sasaran kegiatan KKN di kelurahan Leang-Leang merupakan masyarakat setempat yang terdiri dari anak-anak, remaja, dewasa, dan orang tua, termasuk kegiatan masyarakat yang ada didalamnya. Di antara program yang dirumuskan oleh mahasiswa/i KKN angkatan III STIBA Makassar adalah program Festival Anak Saleh (FAS). Program FAS dinilai dapat berkontribusi bagi peningkatan SDM (Sumber Daya Manusia) di Kelurahan Leang-Leang.

Rencana Pelaksanaan Kegiatan Festival Anak Saleh

\begin{tabular}{ll}
\hline \multicolumn{1}{c}{ Nama Kegiatan } & \multicolumn{1}{c}{ Festival Anak Saleh (FAS) } \\
\hline Tujuan & $\begin{array}{l}\text { Meningkatkan motivasi belajar, semangat } \\
\text { berkompetisi, dan memperkuat keakraban antar } \\
\text { santri. }\end{array}$ \\
\hline Manfaat & $\begin{array}{l}\text { Membina para santri TPA dalam } \\
\text { mengembangkan bakat masing-masing }\end{array}$ \\
\hline Target Waktu & 8-9 Februari 2020 \\
\hline Tempat & $\begin{array}{l}\text { Masjid Nurul Amien Leang-Leang dan Taman } \\
\text { Prasejarah Leang-Leang }\end{array}$ \\
\hline Sasaran & $\begin{array}{l}\text { Seluruh para santri yang ada di kelurahan } \\
\text { Leang-Leang }\end{array}$ \\
\hline Jumlah Peserta & 150 orang anak-anak \\
\hline Biaya & \pm Rp 3.000.000,- \\
\hline Sumber Dana & Pribadi dan Pengadaan Proposal \\
\hline Langkah-Langkah & $\begin{array}{l}\text { Kegiatan FAS ini diawali dengan menjalin } \\
\text { Kegiatan }\end{array}$ \\
& $\begin{array}{l}\text { kelurahahmi ke setiap TPA yang ada di } \\
\text { yaitu TPA Al-Kahfi, TPA Al-Iqro, TPA Al- }\end{array}$ \\
& $\begin{array}{l}\text { Hafidz, TPA At-Taqwa, dan TPA Hidaytul } \\
\text { Ihsan. Kemudian dilakukan pembinaan kepada } \\
\text { para santri pada tiap TPA sebagai persiapan }\end{array}$ \\
& $\begin{array}{l}\text { untuk mengikuti lomba Festival. Lalu para } \\
\text { santri yang telah dibina kemudian didaftarkan } \\
\text { untuk mengikuti lomba yang sesuai dengan }\end{array}$ \\
\hline
\end{tabular}

${ }^{3}$ Pangestu, K. . Pemberdayaan Masjid di Dusun Pakel, Planjan, Saptosari, Gunungkidul, Daerah Istimewa Yogyakarta untuk Kemajuan Ummat. 


bidang masing-masing (bakat yang menonjol
pada anak-anak), yaitu lomba Adzan,
Musabaqah Tilawatil Quran (MTQ),
Musabaqah Hifdzil Quran (MHQ), Cerdas
Cermat Islam (CCI), dan Da'i Cilik.

\section{PEMBAHASAN}

\section{Gambaran Pelaksanaan Festival Anak Soleh (FAS)}

Anak-Anak binaan Mahasiswa KKN angkatan III STIBA Makassar yang berada di Kelurahan Leang-Leang sebelum mengikuti Festival Anak Soleh masih banyak yang belum memiliki pengetahuan Islam dasar dan jumlah hafalan surah-surah pendek yang masih sedikit. Hal itu ditandai dari banyaknya anak-anak belum menghapalkan rukun iman dan Islam. Selain itu, anak-anak belum ada yang menghapal Quran surah AnNaba pada juz 30. Menurut Cholifah ihwal problematika hafalan santri, melalui penelitiannya menunjukkan bahwa hambatan santri dalam menghapal berupa rasa malas, semangat dan keinginannya lemah, tidak mampu mengatur waktu dengan efektif, serta adanya kemiripan ayat-ayat yang satu dengan yang lainya juga dialami oleh beberapa santri Tahfidz dalam menghapal surah. ${ }^{4}$ Dengan demikian, kendala santri tersebut merupakan fokus pengayaan mahasiswa KKN dalam membina santri di Kelurahan Leang-Leang.

Proses pembinaan sebelum kegiatan Festival Anak Saleh. Terdapat 5 (lima) TPA yang dibina oleh Mahasiswa KKN angkatan III STIBA Makassar, yaitu: TPA Al-Kahfi, TPA Al-Iqro, TPA Al-Hafidz, TPA At-Taqwa, TPA Hidaytul Ihsan. Kegiatan TPA pada masing-masing tempat tersebut diikuti oleh sekitar 20-30 orang anak-anak. Pada saat pembinaan dilakukan di setiap TPA yang berada di Kelurahan Leang-Leang, meliputi bimbingan membaca Alquran, hapalan surah-surah pendek, hafalan doa-doa harian, bahasa Arab dasar dan pengetahuan Islam dasar. Sebelum memulai kegiatan pengajaran, pembina mengajukan pertanyaan kepada para santri tentang pengetahuan Islam dasar. Ternyata ditemukan masih banyak santri yang belum mengetahui pengetahuan Islam dasar seperti rukun iman dan Islam, jumlah rakaat shalat fardhu, dan doa-doa dalam shalat semisal doa iftitah, doa ruku', dan lain sebagainya.

Dalam pembimbingan belajar membaca, anak-anak diajari satu persatu dengan saling bergantian, sehingga anak-anak dapat fokus dalam membaca. Sementara itu anakanak yang lain masih menunggu. Seperti halnya anak-anak pada umumnya, disela-sela menunggu giliran untuk pembimbingan membaca, anak-anak saling bermain dengan teman temannya. Anak-anak sangat antusias dalam mengikuti kegiatan TPA ini, secara keseluruhan anak-anak usia SD kelas rendah sudah bisa dalam membaca Iqra', Anakanak SD kelas tinggi sudah bisa membaca Alquran cukup lancar. Selain itu, kegiatan yang

\footnotetext{
${ }^{4}$ Cholifah S. N. Strategi Ustadzah dalam Meningkatkan Hafalan Al Qur’An Santri Putri di Pondok Pesantren Raudlatul Musthofa Pundensari Rejotangan Tulungagung. (2019)
} 
WAHATUL MUJTAMA': Jurnal Pengabdian Masyarakat

Vol. 1, No. 1 (2020) : Hal. 54-66

Website: https://journal.stiba.ac.id

dilakukan adalah menyanyikan nasyid-nasyid Islami baik yang berbahasa Arab maupun Indonesia.

Pasca Festival Anak Saleh. Anak-Anak binaan Mahasiswa KKN angkatan III STIBA Makassar di Kelurahan Leang-Leang setelah mengikuti Festival Anak Soleh sudah banyak yang memiliki pengetahuan Islam dasar dan jumlah hafalan surah-surah pendek yang bertambah serta antusias untuk semakin mempelajari Alquran. Hal itu ditandai dari banyaknya anak-anak yang sudah menghapalkan rukun iman dan Islam, serta doa-doa harian. Selain itu, anak-anak sudah ada yang mampu menghapalkan Quran surah AnNaba pada juz 30. Hal serupa juga dialami oleh Fauzia, dkk., menunjukkan bahwa hasil dari program festival anak saleh yang diselenggarakannya ialah berupa anakanak di Dusun Jatibungkus lebih bersemangat dalam mempelajari agama Islam, kemudian anak-anak Dusun Jatibungkus juga lebih berani untuk menunjukkan bakat serta rasa percaya dirinya makin meningkat. ${ }^{5}$

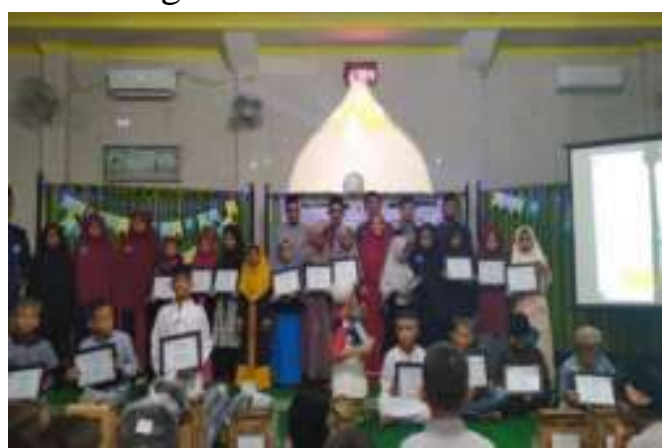

Gambar 1.1. Dokumentasi Setelah Kegiatan FAS

\section{Lomba Azan (LA)}

Sebelum diadakan lomba Adzan para santri di masing-masing TPA diberi pembinaan dan pengajaran ilmu adzan, meliputi makhraj, dan mad (panjang-pendek harakat) pelafalan dalam adzan. Selain itu, teknik-teknik adzan juga diajarkan namun sebelumnya diberikan contoh-contoh muadzin dunia yang terkenal seperti irama adzan Syekh Misyari Rasyid. Pengaturan nafas juga diperhatikan dalam mengajarkan adzan kepada para santri. Anak-anak yang diikutkan dan didaftarkan pada lomba adzan adalah yang berbakat sebagai muadzdzin, dianggap 3 (tiga) terbaik dari masing-masing TPA, sehingga total peserta dari 5 (lima) TPA adalah 15 orang peserta lomba adzan di Festival Anak Saleh Kelurahan Leang-Leang.

Kriteria penilaian adzan terbaik dilihat dari 3 (tiga) aspek yaitu: irama, mahkraj/tajwid, dan adab. Masing-masing bobot penilaian diberi 40 skor pada irama; 30 skor pada makhraj/tajwid; dan 30 skor pada adab. Adapun materi perlombaan adzan adalah lafadz adzan dan do'a setelah adzan. Juklak (petunjuk pelaksanaan) yaitu

\footnotetext{
${ }^{5}$ Fauzia, F., Hasanah, U., Irawati, D. A., Ramadhan, M. H., Wibisono, A. D., Rahman, T., \& Sepdiana, R. D. ARTIKEL dan Feature KKN UAD Divisi XVII. A. 3" Penyelenggaraan Festival Anak Sholeh Di Dusun Jatibungkus, Hargomulyo, Gedangsari, Gunungkidul, DIY". Festival Anak Sholeh, 2018.
} 
WAHATUL MUJTAMA': Jurnal Pengabdian Masyarakat

Vol. 1, No. 1 (2020) : Hal. 54-66

Website: https://journal.stiba.ac.id

perlombaan berdurasi selama 5 menit pada tiap-tiap kontestan. Peserta lomba telah mengambil nomor peserta di PJ (penanggung jawab) lomba adzan setelah pembukaan. Selanjutnya, Peserta lomba maju dan kemudian mengumandangkan adzan dengan durasi yang telah ditentukan. Adapun tujuan dari kegiatan ini sejalan dengan pendapat Subhin yang menyatakan bahwa pada usia dini dan kanak-kanak, anak juga perlu diberi pengajaran tentang ibadah, seperti tentang bersuci, do'a-do'a, dan ayat-ayat pendek, cara mengucap salam, dan sedikit tentang tata cara melaksanakan salat, azan dan ikamah, serta beberapa hal lain yang dikategorikan kepada amal dan perbuatan baik yang diridai Allah. ${ }^{6}$

\section{Musabaqah Tilawatil Quran (MTQ)}

Musabaqah Tilawatil Quran didahului dengan persiapan pembinaan dan pengajaran para santri di TPA Al-Kahfi, TPA Al-Iqro, TPA Al-Hafidz, TPA At-Taqwa, dan TPA Hidaytul Ihsan. Materi pengajaran meliputi makhraj dan tajwid. Adapun irama bergantung pada kecenderungan santri. Santri yang berbakat "mallagu" atau mampu menyelarasakan ketepatan antara irama, tajwid dan mad adalah merupakan calon peserta yang didaftarkan ke Festival Anak Saleh Kelurahan Leang-Leang. Penilaian panitia pun sama, yakni meliputi 3 (tiga) aspek yaitu irama, makhraj/tajwid, dan adab. Masingmasing bobot penilaian diberi 40 skor pada makhraj/ tajwid; 40 skor pada irama; dan 20 skor pada adab. Adapun materi perlombaan yaitu surah Qāf, Al-Mulk dan As-Sajadah.

Petunjuk Pelaksanaan MTQ yaitu peserta mengambil nomor peserta dan maqra di PJ (penanggung jawab) lomba sehari sebelum perlombaan dimulai atau pada hari Jumat siang 7 Februari 2020. Kemudian juri membacakan soal yang berisi nama surah dan nomor ayat dari Alquran (Qāf, Al-Mulk dan As-Sajadah). Selanjutnya peserta membacakan ayat yang telah ditentukan dengan Tartil dan tajwid yg benar. Adapun durasi yang diberlakukan pada tiap-tiap kontestan adalah 10 menit.

Adapun tujuan dari Musabaqah Tilawatil Quran adalah sejalan dengan hasil penelitian yang dilakukan oleh Salbani yang menyatakan bahwa dampak remaja dan anak-anak dalam mengikuti MTQ adalah tampak pada perilaku kehidupan sosial yang baik, yang dahulunya minim tempat pengajian di rumah-rumah sekarang sudah terlihat banyak antusias remaja dan anak-anak yang masih duduk di bangku SD yang ingin mengaji dan menghafal al-Qur'an. ${ }^{7}$ Selain itu, menurut Hasan musabaqah secara tidak langsung memiliki nilai pendidikan, yaitu pendidikan karakter bersaing. ${ }^{8}$ Demikian juga yang diharapkan dalam pagelaran MTQ yang diadakan oleh mahasiswa KKN STIBA Makassar di Kelurahan Leang-Leang Kabupaten Maros.

\footnotetext{
${ }^{6}$ Subhin, M. A. Membentuk Akhlaqul Karimah pada Anak dalam Perspektif Pendidikan Islam. EDUKASI: Jurnal Pendidikan Islam, Vol.5, No.1, 2017: h.47-73.

${ }^{7}$ ISlam, P. P. A., \& Jambi, S. T. S. Dampak Remaja Mengikuti Musabaqah Tilawatil Quran Terhadap Prilaku Hidup Desa Sungai Terap Kecamatan Kumpeh Ulu Tahun 2017.

${ }^{8}$ Hasan, A. R. Pendidikan Karakter Bersaing Dalam Musabaqah Tilawatil Qur'An. Iq (Ilmu Al-Qur'An): Jurnal Pendidikan Islam, Vol.2, No,02, 2019: h.202-216.
} 
WAHATUL MUJTAMA': Jurnal Pengabdian Masyarakat

Vol. 1, No. 1 (2020) : Hal. 54-66

Website: https://journal.stiba.ac.id

\section{Musabaqah Hifdzil Quran (MHQ)}

Musabaqah Hifdzil Quran didahului dengan persiapan pembinaan dan pengajaran para santri di TPA Al-Kahfi, TPA Al-Iqro, TPA Al-Hafidz, TPA At-Taqwa, dan TPA Hidaytul Ihsan. Materi pengajaran meliputi makhraj, tajwid dan kelancaran. Adapun kelancaran bergantung pada kekuatan hafalan (daya ingat) santri. Santri yang berbakat pada aspek kelancaran dan ketepatan dalam "sambung ayat" serta mampu menyelarasakan ketepatan antara makhraj dan tajwid adalah berpeluang besar didaftarkan ke dalam Festival Anak Saleh di Kelurahan Leang-Leang. Adapun penilaian panitia Musabaqah Hifdzil Quran memfokus pada 3 (tiga) hal, yakni meliputi kelancaran, makhraj/tajwid dan adab. Adapun sistem penilaian berlaku bobot skor 40 pada tajwid, 40 skor pada kelancaran, dan 20 skor pada adab. Materi perlombaan MHQ mencakup surah wajib yakni Al-Humazah dan Al Ma'un, Ad Dhuha, dan Al Adiyat. Surah pilihan yakni Al-'ashr, An Nas, dan Ad Dhuha.

Petunjuk Pelaksanaan (Juklak) pada perlombaan MHQ yaitu dimulai dari peserta lomba mengambil nomor peserta di PJ (penanggung jawab) lomba setelah pembukaan. Lalu kemudian soal terdiri dari tiga model pertanyaan meliputi sambung ayat, baca surah lengkap, dan tebak nama surah. Soal berjumlah sebanyak 5 buah soal yang berlaku pada setiap peserta ( 2 sambung ayat, 2 bacaan lengkap, dan 1 nama surah). Selanjutnya, juri membacakan soal secara bergantian, dan maksimal teguran sebanyak 3x (kali) untuk kemudian menggugurkan peserta. Adapun durasi untuk menjawab soal yakni 30 detik setelah pembacaan soal oleh dewan juri, dan durasi setiap soal yakni 2 menit.

Tujuan dari MHQ ini sebagaimana yang dinyatakan oleh Hamdani adalah agar santri selalu membaca al-Qur'an dan berusaha menghafalnya, belajarnya dengan niat yang ikhlas hanya karena Allah Swt, mempelajarinya dengan ber-talaqqi langsung kepada seorang guru agar tidak ada bacaan yang salah, berusaha selalu murojaahnya setiap hari, dan membacanya dengan tartil. ${ }^{9}$

\section{Cerdas Cermat Islam (CCI)}

Cerdas Cermat Islam (CCI) diawali dengan persiapan pembinaan dan pengajaran para santri di 5 (lima) TPA yang ada di Kelurahan Leang-Leang. Materi pengajaran meliputi materi hapalam rukun iman dan Islam, doa-doa harian, bacaan dalam salat, dan seterusnya. Santri yang tampak unggul dalam melahap kisi-kisi soal perlombaan akan didaftarkan ke dalam Festival Anak Saleh di Kelurahan Leang-Leang. Adapun penilaian panitia Cerdas Cermat Islam memfokus pada 3 (tiga) hal, yakni meliputi ketangkasan, ketepatan, dan jawaban paling benar. Distribusi penskoran yaitu terdiri dari:

a. Soal wajib: benar (B) - skor 100, dan salah (S) skor 0.

b. Soal lemparan: benar (B) - skor 50, dan salah (S) skor 0 .

\footnotetext{
${ }^{9}$ Hamdani, A. Y. Manfaat Membaca dan Menghafal Alquran: Studi Living Qur'an Terhadap Manfaat Membaca dan Menghafal Alquran pada Anggota Unit Kegiatan Santri Ponpes Al-Ihsan (Doctoral dissertation, UIN Sunan Gunung Djati Bandung, 2019).
} 
c. Soal rebutan : benar (B) - skor 100, dan salah - skor dikurangi 100.

Adapun materi perlombaan adalah mengacu pada buku materi hafalan santri TK/TPA, berupa doa-doa harian dan adab-adab. Makna dan kandungan surat-surat pendek berupa pengetahuan Islam dasar, Kosakata bahasa arab, dan pengetahuan umum. Juklak (petunjuk) pelaksanaan dari CCI (Cerdas Cermat Islam) ini yaitu:

a. Setiap regu dibagi perkelompok.

b. Satu orang perwakilan setiap regu memilih soal yang telah disiapkan oleh panitia.

c. Peserta tidak diperkenankan membawa alat tulis.

d. Setiap regu diberi durasi waktu selama 30 detik untuk menjawab 1 soal setelah pembacaan soal.

Tujuan dari CCI ini semakna dengan hasil penelitian yang dilakukan oleh Noviyanti yang menyatakan bahwa melalui penerapan Strategi C3T (Cerdas, Cermat, Cepat Dan Tepat) pada mata pelajaran Pendidikan Agama Islam khususnya Perilaku Tercela dapat meningkatkan hasil belajar peserta didik. ${ }^{10}$ Demikian juga yang diharapkan oleh mahasiswa KKN STIBA Makassar dalam perlombaan ini yakni meningkatkan wawasan dan pengetahuan Islam dasar anak-anak.

\section{Da'i Cilik (DC)}

Persiapan penampilan Da'i Cilik diawali dengan persiapan pembinaan dan pengajaran para santri di 5 (lima) TPA yang ada di Kelurahan Leang-Leang. Materi pengajaran meliputi materi hapalan materi ceramah atau kultum, pelatihan kepercayaan diri tampil di depan umum, dan pelatihan pengaturan mimik dan intonasi dalam penyampaian ceramah. Santri yang berbakat sebagai penceramah akan didaftarkan ke dalam Festival Anak Saleh di Kelurahan Leang-Leang. Adapun penilaian panitia Cerdas Cermat Islam memfokus pada 3 (tiga) hal, yakni materi ceramah, kesesuaian dan ketepatan penggunaan nas, dan kepercayaan diri tampil di depan umum.

Secara khusus sistem penilaian mencakup pada materi dengan bobot skor 20 . Adab skor 20 dan Intonasi juga dengan skor 20. Dari sisi ketepatan waktu diberi skor 20, dan juga mimik dengan skor 20. Adapun materi perlombaan sifatnya independen, dalam artian peserta diberi keleluasaan dalam menyusun materi ceramahnya. Petunjuk Pelaksanaan perlombaan da'i cilik ini yaitu:

a. Durasi waktu minimal 3 menit dan maksimal 5 menit

b. Peserta lomba mengumpulkan naskah kultum sebanyak tiga rangkap ke PJ lomba

c. Peserta lomba mengambil nomor peserta di PJ lomba setelah pembukaan

d. Peserta menyampaikan kultum berbahasa indonesia dengan durasi yang telah ditentukan.

\footnotetext{
${ }^{10}$ Noviyanti, R. Penerapan Strategi C3T (Cerdas, Cermat, Cepat dan Tepat) dalam Meningkatkan Hasil Belajar Mata Pelajaran Pendidikan Agama Islam Peserta Didik Kelas VIII di SMP PGRI 06 Bandar Lampung (Doctoral dissertation, UIN Raden Intan Lampung, 2017).
} 
WAHATUL MUJTAMA': Jurnal Pengabdian Masyarakat

Vol. 1, No. 1 (2020) : Hal. 54-66

Website: https://journal.stiba.ac.id

Tujuan dari lomba Da'i Cilik ini sejalan dengan hasil penelitian yang dilakukan oleh Arrizal yang mengemukakan bahwa pelaksanaan kegiatan ekstrakurikuler DACIL (Da'i Cilik) di SDN Kauman 2 Malang dikatakan berhasil karena dapat membentuk dan membuat siswa menjadi lebih percaya diri terlihat dari sikap siswa yang berbicara dengan tegas yang tidak ragu, percaya pada diri sendiri, dan menunjukkan keberanian saat mengikuti pelajaran di kelas atau kegiatan ekstrakurikuler lainnya. ${ }^{11}$ Demikian juga yang diharapkan oleh mahasiswa KKN STIBA Makassar dalam perlombaan ini yakni meningkatkan minat, bakat, keberanian, dan kepercayaan diri para santri.

\section{Pengalaman Menarik dan Faktor Pendukung Kegiatan FAS}

Pengalaman yang paling menarik pada saat proses pelaksanaan Festival Anak Soleh yaitu ketika beberapa peserta masih menolak untuk tampil dikarenakan kurang percaya diri, bahkan beberapa peserta menangis dan tampil ke depan panggung ditemani orang tua.

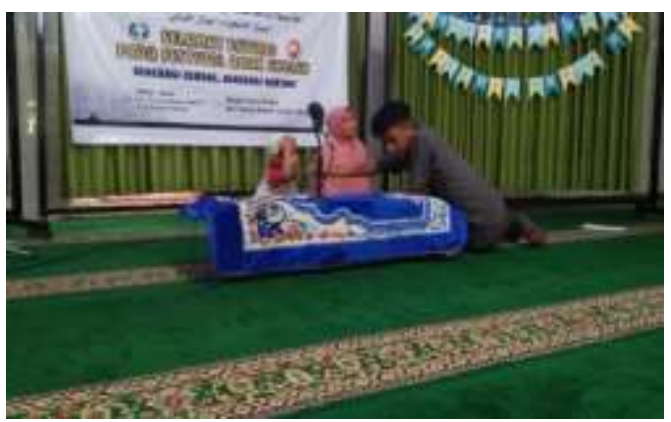

Gambar. 1.2. Peserta FAS Ditemani Oleh Orang Tuanya Di Atas Panggung

Festival Anak Soleh sangat mendapat respon dari masyarakat Kelurahan LeangLeang karena merupakan kegiatan yang sangat mendidik bagi anak-anak di Kelurahan Leang-Leang khususnya dalam membantu meningkatkan pengetahuan Islam anak-anak di Kelurahan Leang-Leang.

\section{Kendala, Solusi, dan Follow Up Kegiatan FAS}

Kurangnya mobilisasi atau pengarahan untuk para peserta kegiatan PAS sehingga memperlambat jalannya kegiatan. Memaksimalkan mobilisasi yang ada untuk mengantar jemput peserta lomba dari rumahnya demi kesuksesan kegiatan. Untuk Kelanjutan Program Kerja maka anak-anak binaan Mahasiswa STIBA di setiap TPA dikembalikan kepada Guru TPA di Kelurahan Leang-Leang untuk melanjutkan pembinaan.

\footnotetext{
${ }^{11}$ Arrizal, S. Penerapan Ekstrakurikuler Da'i Cilik (Dacil) dalam Pembentukan Karakter Percaya Diri Peserta Didik SDN Kauman 2 Malang (Doctoral Dissertation, University of Muhammadiyah Malang, 2019).
} 


\section{KESIMPULAN}

Tujuan dari Pengabdian Kepada Masyarakat (PkM) dalam bentuk program KKN ini adalah untuk membantu pengembangan SDM di Kelurahan Leang-Leang Kabupaten Maros. Program Festival Anak Saleh (FAS) ini merupakan ajang dalam menumbuhkan minat dan bakat anak-anak usia sekolah dasar, tentunya bertujuan khusus dalam meningkatkan kompetensi dari sisi pengetahuan dasar keislaman, perilaku ibadah, adab, dan akhlak keseharian anak. Hasil dari kegiatan FAS ini mampu meningkatkan antusias dan motivasi belajar agama Islam anak-anak di Kelurahan Leang-Leang. Selain itu, ditengarai tampak perubahan dari aspek perilaku ibadah, adab, dan akhlak pada diri anak atau santi-santriwati.

\section{DAFTAR PUSTAKA}

Arrizal, S. (2019). Penerapan Ekstrakurikuler Da'I Cilik (Dacil) Dalam Pembentukan Karakter Percaya Diri Peserta Didik Sdn Kauman 2 Malang (Doctoral dissertation, University of Muhammadiyah Malang).

Cholifah, S. N. (2019). Strategi Ustadzah dalam Meningkatkan Hafalan Al Qur'An Santri Putri di Pondok Pesantren Raudlatul Musthofa Pundensari Rejotangan Tulungagung.

Fauzia, F., Hasanah, U., Irawati, D. A., Ramadhan, M. H., Wibisono, A. D., Rahman, T., \& Sepdiana, R. D. (2018). Artikel Dan Feature KKN UAD Divisi XVII. A. 3" Penyelenggaraan Festival Anak Sholeh di Dusun Jatibungkus, Hargomulyo, Gedangsari, Gunungkidul, DIY". festival anak sholeh.

Hamdani, A. Y. (2019). Manfaat membaca dan menghafal alquran: Studi Living Qur'an terhadap manfaat membaca dan menghafal Alquran pada anggota unit kegiatan santri Ponpes Al-Ihsan (Doctoral dissertation, UIN Sunan Gunung Djati Bandung).

Hasan, A. R. (2019). Pendidikan Karakter Bersaing dalam Musabaqah Tilawatil Qur'an. IQ (Ilmu Al-qur'an): Jurnal Pendidikan Islam, Vol.2, N0.02, h.202-216.

ISLAM, P. P. A., \& JAMBI, S. T. S. Dampak Remaja Mengikuti Musabaqah Tilawatil Quran Terhadap Prilaku Hidup Desa Sungai Terap Kecamatan Kumpeh Ulu Tahun 2017.

Maryani, I., \& Noveryal, N. (2019). Penyelenggaraan Festival Anak Sholeh di Dusun Seropan I, Desa Munthuk, Kecamatan Dlingo. Jurnal Pemberdayaan: Publikasi Hasil Pengabdian Kepada Masyarakat, Vol.3, No.2, h.131-136.

Noviyanti, R. (2017). Penerapan Strategi C3T (Cerdas, Cermat, Cepat dan Tepat) Dalam Meningkatkan Hasil Belajar Mata Pelajaran Pendidikan Agama Islam Peserta Didik 
WAHATUL MUJTAMA': Jurnal Pengabdian Masyarakat

Vol. 1, No. 1 (2020) : Hal. 54-66

Website: https://journal.stiba.ac.id

Kelas VIII di SMP PGRI 06 Bandar Lampung (Doctoral dissertation, UIN Raden Intan Lampung).

Pangestu, K. (2019). Pemberdayaan Masjid di Dusun Pakel, Planjan, Saptosari, Gunungkidul, Daerah Istimewa Yogyakarta untuk Kemajuan Ummat.

Profil Kelurahan Leang-Leang Tahun 2019.

Subhin, M. A. (2017). Membentuk Akhlaqul Karimah pada Anak dalam Perspektif Pendidikan Islam. EDUKASI: Jurnal Pendidikan Islam, Vol.5, No.1, h.47-73. 